\title{
AKTIVITAS TABIR SURYA EKSTRAK AKAR BANDOTAN (AGERATUM CONYZOIDES L.)
}

\author{
Meilisa Athiyah, Islamudin Ahmad, Laode Rijai \\ Laboratorium Penelitian dan Pengembangan Kefarmasian FARMAKA TROPIS, Fakultas \\ Farmasi, Universitas Mulawarman, Samarinda, Kalimantan Timur \\ Email: icha.athiyyah@gmail.com
}

\begin{abstract}
A research has been done with title "Sunscreen Activity of Bandotan (Ageratum conyzoides L.) Roots Extracts". The research aims to know the sunscreen activity by calculate the percentage transmission of erythema and pigmentation parameters in vitro. In vitro test using UV-Vis spectrophotometry method at $\lambda 292,5-372,5 \mathrm{~nm}$. The results showed that the sunscreen activity of methanol extract from bandotan roots has sunscreen category as fast tanning, suntan standard, extra protection, and sunblock at concentration 200 to $800 \mathrm{ppm}$. Meanwhile sunscreen activity of ethyl acetate fraction from bandotan roots has sunscreen category as fast tanning, suntan standard, extra protection, and sunblock at concentration 50 to $200 \mathrm{ppm}$.
\end{abstract}

Keywords: Bandotan (Ageratum conyzoides L.), Sunscreen, Sunblock, Extra protection, Suntan standard, Fast tanning.

\begin{abstract}
ABSTRAK
Telah dilakukan penelitian dengan judul "Aktivitas Tabir Surya Ekstrak Akar Herba Bandotan (Ageratum conyzoides L.)". Penelitian ini bertujuan untuk mengetahui aktivitas tabir surya dengan parameter persentase transmisi eritema dan transmisi pigmentasi secara in vitro. Pengujian in vitro menggunakan metode spektrofotometri UV-Vis pada $\lambda 292,5-$ $372,5 \mathrm{~nm}$. Hasil pengujian menujukkan bahwa ekstrak kasar metanol memiliki aktivitas tabir surya kategori fast tanning, suntan standard, proteksi ekstra, dan sunblock pada konsentrasi 200 - 800 ppm; sedangkan profil aktivitas tabir surya fraksi etil asetat pada kategori fast tanning, suntan standard, proteksi ekstra, dan sunblock pada konsentrasi 50200 ppm.
\end{abstract}

Kata kunci: Bandotan (Ageratum conyzoides L.), Tabir surya, Sunblock, Proteksi ekstra, Suntan standard, Fast tanning.

\section{PENDAHULUAN}

Data empiris akar bandotan $(A$. conyzoides L.) digunakan sebagai bahan ramuan bedak dingin dicampur dengan beras oleh masyarakat Indonesia termasuk di Kalimantan Timur. Bedak dingin tersebut biasanya digunakan oleh para wanita untuk melindungi kulit dari paparan sinar matahari di siang hari. Masyarakat percaya bahwa bedak dingin tersebut dapat melindungi kulit dari sinar matahari langsung dengan efektif sehingga kulit tidak terjadi perubahan warna. Radiasi sinar matahari yang 
sampai ke bumi untuk wilayah Indonesia memang berlimpah karena Indonesia merupakan wilayah tropis terlebih Kalimantan yang dilewati oleh garis khatulistiwa.

Radiasi ultra violet pada panjang gelombang antara 292,5-372,5 $\mathrm{nm}$ (daerah UV B) berpotensi menimbulkan kerusakan pada kulit, diantaranya mengalami eritema (pemerahan pada kulit), sedangkan pada panjang gelombang 322,5-372,5 nm (UV A) menyebabkan penuaan kulit [1]. Bedak dingin tradisional ini dengan berbahan aktif akar bandotan merupakan bedak tradisional Kalimantan diharapkan dapat melindung kulit dari peristiwa tersebut. Dalimartha [2] melaporkan bahwa akar bandotan mengandung kumarin, yang dikenal sebagai senyawa aktif tabir surya yang baik walaupun terhadap paparan tinggi cahaya matahari. Senyawa dari golongan kumarin telah dibuat menjadi sediaan tabir surya dan kosmetik [3].

Oleh karena itu, perlu dilakukan pengujian dasar untuk mengetahui aktivitas tabir surya dari akar herba bandotan yang diketahui mengandung senyawa-senyawa kumarin. Uji aktivitas awal dari bahan tabir surya dapat dilakukan secara in vitro menggunakan metode sederhana yaitu pengukuran $\%$ transmisi eritema (Te) dan \% transmisi pigmentasi (Tp) berdasarkan nilai absorbansi pada spektrofotometri [4].

\section{METODE PENELITIAN}

\section{Bahan}

Dikumpulkan tumbuhan bandotan (A. conyzoides L.) yang diambil di daerah Kecamatan Gunung Tabur, Kabupaten Berau, Kalimantan Timur. Dipilih sampel akar secara acak dengan melihat fisik akar (masih segar atau tidak layu, tidak terlalu tua atau terlalu muda). Diambil bagian akarnya dan dibersihkan dari tanah. Kemudian, ditimbang dan diperoleh sampel segar seberat 2500 gram. Setelah itu dicuci pada air, diperkecil ukurannya dengan cara memotong atau menggunting sampel, dikeringkan dengan cara diletakkan dalam ruangan dengan sirkulasi udara yang baik dan tidak terkena paparan matahari secara langsung. Kemudian, disortasi kering sehingga diperoleh simplisia kering akar bandotan seberat 470 gram yang siap diekstraksi.

\section{Peralatan}

Peralatan penting yang digunakan alat ekstraksi (wadah maserasi dan rotary evaporator), Spektrometer UV-VIS Double Beam Dynamica Halo $D B-20 S$ dan sejumlah peralatan penunjang.

\section{Ekstraksi}

Sebanyak 470 g simplisia akar bandotan dimaserasi dengan metanol teknik dengan pergantian pelarut setiap 35 hari. Larutan ekstrak dengan pelarut metanol yang diperoleh segera diuapkan pelarutnya dengan menggunakan rotary evaporator, hingga mendapatkan ekstrak akar bandotan sebanyak 28,6 g. Sebagian ekstrak kasar metanol tersebut (10 g) difraksinasi dengan etil asetat yang diduga pada fraksi tersebut mengandung sejumlah senyawa-senyawa kumarin. Hasil akhir ekstraksi diperoleh ekstrak kasar metanol 28,6 g dan ekstrak fraksi etilasetat 3,48 g. Kedua ekstrak tersebut siap untuk dilakukan pengujian tabir surya.

\section{Pengujian Tabir Surya}

Ekstrak kasar metanol dan fraksi etil asetat masing-masing dibuat larutan stok dengan konsentrasi 1000 ppm sebanyak $100 \mathrm{~mL}$. Masing-masing larutan stok tersebut diencerkan dalam beberapa variasi konsentrasi, yaitu untuk ekstrak metanol: 150; 200; 250; 300; 350; $450 ; 500 ; 550 ; 600 ; 650 ; 700 ; 750$; dan $800 \mathrm{ppm}$, dan untuk fraksi etil asetat dengan seri konsentrasi: $25 ; 50 ; 75 ; 100$; 150; dan 200 ppm. Penentuan seri 
konsentrasi tersebut berdasarkan hasilhasil uji pendahuluan. Setiap konsentrasi tersebut dilakukan pengukuran absorbansi dengan menggunakan Spektrometer UV-VIS Double Beam Double Beam Dynamica Halo DB-20S pada panjang gelombang UV B yaitu 292,5-372,5 $\mathrm{nm}$ dengan interval $5 \mathrm{~nm}$ dan UV A pada 322,5-372,5 nm. Setiap pengukuran dilakukan triplo atau tiga kali ulangan.

\section{Analisis Data}

Penentuan aktivitas tabir surya berdasarkan adanya serapan (absorben) pada panjang gelombang 292,5-372,5 nm dan 322,5-372,5 nm ; sedangkan penentuan kategori tabir surya berdasarkan nilai \% transmisi eritema $(\% \mathrm{Te})$ dan $\%$ transmisi pigmentasi (\%Tp). Penentuan nilai transmisi (T) menggunakan rumus berikut dengan mengalikan $100 \%$ untuk mendapatkan nilai persentase, yaitu:

$$
\mathrm{A}=-\log \mathrm{T}
$$

Selanjutnya, penentuan \% transmisi eritema (\%Te) dan $\%$ transmisi pigmentasi (\% $\mathrm{Tp}$ ) mengunakan rumus berikut:

$$
\begin{aligned}
\% \text { Transmisi eritema }= & \frac{E e}{\sum F e}= \\
& \frac{\sum(T x F e)}{\sum F e}
\end{aligned}
$$

$\%$ Transmisi pigmentasi $=\frac{E p}{\sum F p}=$

$$
\frac{\sum(T x F p)}{\sum F p}
$$

(Balsam dan Sagarin, 1972)

$$
\begin{aligned}
& \text { Keterangan : } \\
& \mathrm{Ee}= \text { Banyaknya fluks eritema yang diteruskan } \\
& \text { oleh tabir surya } \\
& \mathrm{Ep}= \text { Banyaknya fluks pigmentasi yang } \\
& \text { diteruskan oleh tabir surya } \\
& \mathrm{T}= \text { Transmisi } \\
& \mathrm{Fe}= \text { Fluks eritema yang nilainya pada panjang } \\
& \text { gelombang tertentu } \\
& \mathrm{Fp}= \text { Fluks pigmentasi yang nilainya pada } \\
& \text { panjang gelombang tertentu } \\
& \text { Penilaian kategori/profil tabir } \\
& \text { surya dilakukan berdasarkan Tabel } 1 .
\end{aligned}
$$

Tabel 1. Kategori Penilaian Aktivitas Tabir Surya (Balsam dan Sagarin, 1972)

\begin{tabular}{ccc}
\hline \multirow{2}{*}{ Kategori } & \multicolumn{2}{c}{$\%$ Transmisi } \\
\cline { 2 - 3 } & Eritema & Pigmentasi \\
\hline Sunblock & $<1 \%$ & $3-40 \%$ \\
Proteksi ekstra & $1-6 \%$ & $42-86 \%$ \\
Suntan standard & $6-12 \%$ & $45-86 \%$ \\
Fast tanning & $10-18 \%$ & $45-86 \%$ \\
\hline
\end{tabular}

\section{HASIL DAN PEMBAHASAN}

Aktivitas tabir surya adalah kemampuan suatu molekul atau campuran molekul kimia menyerap sinar ultraviolet pada panjang gelombang UVA $(322,5-372,5 \mathrm{~nm})$ sebagai penyebab pigmentasi dan UV B $(292,5-337,5 \mathrm{~nm})$ sebagai penyebab eritema pada kulit. Berdasarkan potensi tersebut maka suatu bahan yang mengandung molekul kimia yang bersifat tabir surya dapat digunakan sebagai pelindung kulit atau kosmetik. Hasil penelitian kemampuan tabir surya akar bandotan ditunjukkan pada Tabel 2 . 
Tabel 2. Hasil Aktivitas Tabir Surya Akar Bandotan dalam Persentase Transmisi Eritema dan Pigmentasi

\begin{tabular}{|c|c|c|c|c|}
\hline Konsentrasi (ppm) & $\% \mathrm{Te}$ & Kategori & $\% \mathrm{Tp}$ & Kategori \\
\hline \multicolumn{5}{|l|}{ Ekstrak Metanol } \\
\hline 150 & 23,71 & - & 17,23 & Sunblock \\
\hline 200 & 15,26 & Fast tanning & 9,47 & Sunblock \\
\hline 250 & 10,90 & Fast tanning-Suntan standard & 5,83 & Sunblock \\
\hline 300 & 7,40 & Suntan standard & 3,20 & Sunblock \\
\hline 350 & 5,14 & Proteksi ekstra & 1,72 & - \\
\hline 400 & 3,74 & Proteksi ekstra & 0,98 & - \\
\hline 450 & 3,12 & Proteksi ekstra & 0,69 & - \\
\hline 500 & 2,47 & Proteksi ekstra & 0,47 & - \\
\hline 550 & 1,86 & Proteksi ekstra & 0,25 & - \\
\hline 600 & 1,57 & Proteksi ekstra & 0,19 & - \\
\hline 650 & 1,41 & Proteksi ekstra & 0,17 & - \\
\hline 700 & 1,21 & Proteksi ekstra & 0,15 & - \\
\hline 750 & 1,01 & Proteksi ekstra & 0,14 & - \\
\hline 800 & 0,89 & Sunblock & 0,14 & - \\
\hline \multicolumn{5}{|l|}{ Fraksi Etil Asetat } \\
\hline 25 & 35,77 & - & 30,59 & Sunblock \\
\hline 50 & 14,48 & Fast tanning & 9,54 & Sunblock \\
\hline 75 & 6,53 & Suntan standard & 2,94 & - \\
\hline 100 & 4,19 & Proteksi ekstra & 1,36 & - \\
\hline 150 & 1,73 & Proteksi ekstra & 0,25 & - \\
\hline 200 & 0,86 & Sunblock & 0,14 & - \\
\hline
\end{tabular}

\section{Aktivitas Tabir Surya}

Hasil penelitian yang ditunjukkan Tabel 2 menggambarkan bahwa aktivitas tabir surya ekstrak kasar (Crude extracts) metanol mulai memberikan arti pada konsentrasi 200 ppm, sedangkan 150 ppm tidak memiliki fungsi yang berarti berdasarkan empat kategori tabir surya yang diharapkan. Selanjutnya untuk ekstrak fraksi etilasetat memberikan arti mulai pada konsentrasi $50 \mathrm{ppm}$, yang bermakna lebih baik dari pada ekstrak kasar metanol. Hal ini menggambarkan bahwa fraksinasi ekstrak kasar metanol untuk akar bandotan menjadi sangat penting untuk meningkatkan aktivitas tabir surya yang lengkap.

\section{Profil Tabir Surya Ekstrak Akar Bandotan}

\section{a. Kategori Sunblock}

Sunblock dalam pengertian tabir surya yaitu kemampuan suatu molekul kimia memproteksi secara total sinar matahari penyebab eritema dan pigmentasi dari sinar uvltraviolet yang spesifik pada UV A panjang gelombang 322,5-372,5 nm dan pada UV B panjang gelombang 292,5-337,5 $\mathrm{nm}$.

Hasil penelitian tabir surya terhadap akar bandotan menunjukkan bahwa pada konsentrasi 800 ppm ekstrak kasar metanol telah bersifat sunblock untuk eritema; sedangkan untuk pigmentasi terjadi pada konsentrasi 150 - 
300 ppm. Hal ini menggambarkan bahwa untuk keperluan eritema dan pigmentasi penggunaan ekstrak kasar metanol harus dilakukan dalam sediaan kosmetik yang berbeda, karena pada konsentrasi 800 ppm tidak menunjukkan sunblock untuk pigmentasi, sedangkan untuk eritema spesifik pada konsentrasi 800 ppm. Selanjutnya, kemampuan sunblock untuk ekstrak fraksi etilasetat untuk eritema terjadi pada konsentrasi 200 ppm, sedangkan untuk pigmentasi terjadi pada konsentrasi 25 - 50 ppm. Kedua ekstrak tersebut jika diperuntukan sebagai sunblock yang terbaik untuk eritema karena pada konsentrasi rendah telah memberikan efek sunblock untuk keperluan pigmentasi sedangkan untuk eritema pada konsentrasi tinggi yaitu 800 ppm untuk ekstrak kasar metanol dan 200 ppm untuk ekstrak fraksi etil asetat.

\section{b. Kategori Proteksi Ekstra}

Proteksi ekstra dalam pengertian tabir surya yaitu kemampuan suatu molekul kimia memproteksi kulit yang sensitif dengan cara mengabsorbsi $95 \%$ atau lebih radiasi sinar UV pada panjang gelombang 290-320 nm [4]. Sehingga lebih banyak melindungi kulit dari paparan sinar UV B penyebab eritema kulit.

Hasil penelitian tabir surya terhadap akar bandotan menunjukkan bahwa pada konsentrasi 350-750 ppm ekstrak kasar metanol telah bersifat proteksi ekstra untuk eritema; sedangkan untuk pigmentasi tidak berpotensi terhadap perlindungan kejadian pigmentasi. Hal ini menggambarkan bahwa untuk keperluan eritema dan pigmentasi penggunaan ekstrak kasar metanol harus dilakukan dalam sediaan kosmetik yang berbeda, karena pada konsentrasi 350-750 ppm tidak menunjukkan proteksi ekstra untuk pigmentasi, sedangkan untuk eritema spesifik pada konsentrasi 350-750 ppm. Selanjutnya, kemampuan proteksi ekstra untuk ekstrak fraksi etil asetat untuk eritema terjadi pada konsentrasi $100-150$ ppm, sedangkan untuk pigmentasi tidak berpotensi terhadap perlindungan kejadian pigmentasi. Kedua ekstrak tersebut jika diperuntukkan sebagai proteksi ekstra yang terbaik untuk eritema karena pada konsentrasi 350-750 ppm ekstrak metanol dan pada konsentrasi 100-150 ppm ekstrak fraksi etil asetat telah memberikan efek proteksi ekstra untuk keperluan eritema. Sedangkan untuk pigmentasi kedua ekstrak tidak berpotensi sebagai proteksi ekstra.

\section{c. Kategori Suntan Standard}

Suntan Standard dalam pengertian tabir surya yaitu kemampuan suatu molekul kimia memproteksi kulit normal atau yang tidak sensitif dengan menyerap sebagian besar sinar UV B dan menyerap sedikit sinar UV A [6]. Menurut Wilkinson dan Moore [4] suntan standard mengandung bahan yang disebut tabir surya yang mengabsorbsi sedikitnya $85 \%$ radiasi sinar UV pada panjang gelombang 290-320 mn tetapi meneruskan sinar UV pada panjang gelombang yang lebih besar dari $320 \mathrm{~nm}$ dan menghasilkan kulit coklat ringan yang bersifat sementara.

Hasil penelitian tabir surya terhadap akar bandotan menunjukkan bahwa pada konsentrasi 300 ppm ekstrak kasar metanol berpotensi suntan standard untuk eritema; sedangkan untuk pigmentasi tidak berpotensi suntan standard terhadap perlindungan kejadian pigmentasi. Hal ini menggambarkan bahwa untuk keperluan eritema dan pigmentasi penggunaan ekstrak kasar metanol harus dilakukan dalam sediaan kosmetik yang berbeda, karena pada konsentrasi 250-300 ppm tidak menunjukkan suntan standard untuk pigmentasi, sedangkan untuk eritema spesifik pada konsentrasi 250-300 ppm. Selanjutnya, kemampuan suntan standard untuk ekstrak fraksi etil asetat untuk eritema terjadi pada konsentrasi 75 
ppm, sedangkan untuk pigmentasi tidak berpotensi terhadap perlindungan kejadian pigmentasi. Kedua ekstrak tersebut jika diperuntukkan sebagai suntan standard yang terbaik untuk eritema karena pada konsentrasi 250-300 ppm ekstrak metanol dan pada konsentrasi 75 ppm ekstrak fraksi etil asetat telah memberikan efek proteksi ekstra untuk keperluan eritema. Sedangkan untuk pigmentasi kedua ekstrak tidak berpotensi sebagai suntan standard.

\section{d. Kategori Fast Tanning}

Fast tanning dalam pengertian tabir surya yaitu kemampuan suatu molekul kimia yang menyerap sinar UV A dan UV B paling sedikit. Menurut Cumpelik [6] fast tanning mampu meneruskan sebesar $15 \%$ sinar UV B penyebab eritema. Syarat tanning ialah harus mampu memberikan transmisi penuh pada rentang panjang gelombang 300-400 nm untuk memberikan efek terhadap penggelapan maksimum pada kulit [4].

Hasil penelitian tabir surya terhadap akar bandotan menunjukkan bahwa pada konsentrasi 200-250 ppm ekstrak kasar metanol berpotensi fast tanning untuk eritema; sedangkan untuk pigmentasi tidak berpotensi fast tanning terhadap perlindungan kejadian pigmentasi. Hal ini menggambarkan bahwa untuk keperluan eritema dan pigmentasi penggunaan ekstrak kasar metanol harus dilakukan dalam sediaan kosmetik yang berbeda, karena pada konsentrasi 200-250 ppm tidak menunjukkan fast tanning untuk pigmentasi, sedangkan untuk eritema spesifik pada konsentrasi 200-250 ppm. Selanjutnya, kemampuan fast tanning untuk ekstrak fraksi etil asetat untuk eritema terjadi pada konsentrasi 50 ppm, sedangkan untuk pigmentasi tidak berpotensi terhadap perlindungan kejadian pigmentasi. Kedua ekstrak tersebut jika diperuntukkan sebagai fast tanning yang terbaik untuk eritema karena pada konsentrasi 200-250 ppm ekstrak metanol dan pada konsentrasi 50 ppm ekstrak fraksi etil asetat telah memberikan efek proteksi ekstra untuk keperluan eritema. Sedangkan untuk pigmentasi kedua ekstrak tidak berpotensi sebagai fast tanning.

\section{KESIMPULAN}

1. Ekstrak kasar matenol dan fraksi etilasetat akar bandotan memiliki aktivitas tabir surya dengan kategori sunblock, proteksi ekstra, suntan standard dan fast tanning untuk perlindungan terjadinya eritema dan pigmentasi oleh ultraviolet dari sinar matahari

2. Kemampuan proteksi ekstrak kasar metanol untuk kategori Sunblock (proteksi total) terhadap kejadian eritema pada konsentrasi 800 ppm, dan untuk kejadian pigmentasi pada konsentrasi 150-300 ppm; kategori proteksi ekstra terhadap kejadian eritema pada konsentrasi 350-750 ppm, dan tidak berpotensi terhadap perlindungan kejadian pigmentasi; kategori Suntan standard terhadap kejadian eritema pada konsentrasi 250-300 ppm, dan tidak berpotensi terhadap perlindungan kejadian pigmentasi; kategori fast tanning terhadap kejadian eritema pada konsentrasi 200-250 ppm, dan tidak berpotensi terhadap perlindungan kejadian pigmentasi

3. Kemampuan proteksi ekstrak fraksi etil asetat untuk kategori Sunblock (proteksi total) terhadap kejadian eritema pada konsentrasi 200 ppm, dan untuk kejadian pigmentasi pada konsentrasi 25-50 ppm; kategori proteksi ekstra terhadap kejadian eritema pada konsentrasi 100-150 ppm, dan tidak berpotensi terhadap perlindungan kejadian pigmentasi; kategori Suntan Standard terhadap kejadian eritema pada konsentrasi 75 ppm, dan tidak berpotensi terhadap 
perlindungan kejadian pigmentasi; kategori fast tanning terhadap kejadian eritema pada konsentrasi 50 ppm, dan tidak berpotensi terhadap perlindungan kejadian pigmentasi.

\section{DAFTAR PUSTAKA}

1. Lowe, J, Nicholas and N. A. Shaath. 1997. Sunscreens: Developtment, Evaluation, and Regulatory Aspert. Marcel Dekker Inc.: New York.

2. Dalimartha, Setiawan. 2000. Atlas Tumbuhan Obat Indonesia Jilid 2. Trubus Agriwidya: Jakarta.
3. Heinrich, Michael. 2009. Farmakognosi dan Fitoterapi. EGC: Jakarta.

4. Wilkinson, J.B dan Moore R. J.. 1982. Harry's Cos-meticology, 7th Edition. Chemical Publishing: New York.

5. Balsam and Sagarin. 1972. Cosmetiscs Science and Technology. Wiley Interscience. London.

6. Cumpelik BS. 1972. Analitical Procedures and Evaluation of Sunscreen. Journal of Cosmetics Chemist., 23:333-345. 